Review article

\title{
The importance of ethical codes in nursing care
}

\author{
Kristýna Toumová *, Lucie Havierniková, Jana Kimmerová, Věra Hellerová, Valérie Tóthová, \\ Ivana Chloubová \\ University of South Bohemia, Faculty of Health and Social Sciences, Institute of Nursing, Midwifery and Emergency Care, České Budějovice, \\ Czech Republic
}

\begin{abstract}
Introduction: The ethics of the nursing profession is formulated by the International Code of Ethics for Nurses, which is valid for all nurses around the world. The importance of this code is indisputable, especially in situations that require ethical conduct. However, as the current health care system evolves, so must the content of these codes. The stimuli for these updates can be provided by the nurses in practice.

Objective: The aim is to point out the importance and use of codes of ethics in contemporary nursing in various countries and the need to innovate the code of ethics in the Czech environment.

Methods: A literary search for keywords according to PICO was performed using Boolean operators. Professional resources were searched in scientific electronic databases (EBSCO, PubMed, ProQuest, WOS).

Results: A total of 252 sources were searched. 153 sources that met the required criteria were subsequently subjected to critical analysis. Of this number, 10 studies were used for the final analysis, which focused on the views of nurses on codes of ethics and ethical conflicts in the practice of nurses.

Conclusions: The studies examined show that nurses are aware of the importance of the code of ethics. However, whilst most nurses are generally aware of the code, many do not know the exact content and how it should help them in practice. During the provision of nursing care, nurses encounter many ethical dilemmas, especially in the area of differences in some values. Some studies have found that nurses sometimes perceive that patients' rights are higher priority than their own rights. It is therefore important that codes of ethics do not forget to promote the rights of nurses themselves.
\end{abstract}

Keywords: Code of Ethics; Nursing Practice; Opinions of Nurses on the Code of Ethics

\section{Introduction}

To ensure quality nursing care in today's world, nursing can no longer be perceived only as personal healthcare and the provision of incentives to ensure this care (Meleis, 2011). It must be perceived in its entirety. Through the care provided, this includes the recipients of care, but also its providers and their characteristics. It is nurses, as providers of nursing care, who have significant potential for ensuring and maintaining the health of the population (Jahromi et al., 2018; WHO, 2020). However, for the quality and effective use of this potential, it is necessary to know, build and cultivate professional values. These directly influence professional decisions, actions, and behaviour. As a result, they form the basis of high-quality and ethical nursing care (Jahromi et al., 2018; Poorchangizi et al., 2017).

Being a nurse today is not just about completing a qualification. It is associated with the need to go through the whole process of professional socialization (Zarshenas et al., 2014).
In this context, knowledge of ethics seems important. Ethics, through codes of ethics, enters nursing as a factor associated with the effort to improve nursing care in all its aspects (Mohajjel-Aghdam et al., 2013). Codes of ethics then provide certain guidelines for shaping ethical behaviour and determine what values and beliefs should be adopted (Bijani et al., 2017). The goal of this article is to point out the importance and use of the codes of ethics in contemporary nursing in various countries and the need to innovate the code of ethics in the Czech environment.

The ethics of the nursing profession is generally formulated in the International Code of Ethics for Nurses, which was first adopted by the Council of Nurses in 1953. Since then, it has undergone several modifications. Its preamble states that nurses have four basic responsibilities, namely to promote health, prevent disease, restore health, and alleviate suffering. At the same time, it states that nursing also includes respect for human rights (including those given by culture) and caring for recipients with regard to their individuality (ICN, 2012; 2020). However, ethical issues in the nursing profession are

\footnotetext{
* Corresponding author: Kristýna Toumová, University of South Bohemia, Faculty of Health and Social Sciences, Institute of Nursing, Midwifery and Emergency Care, U Výstaviště 26, 37005 České Budějovice, Czech Republic; e-mail: toumova@zsf.jcu.cz http://doi.org/10.32725/kont.2021.021
} 
not only related to the direct provision of care to patients and the possible occurrence of ethical dilemmas. They are also associated with leading nursing teams and the approach to oneself as a caregiver and human entity (Aitamaa et al., 2019). In the results of their cross-sectional study, Aitamaa et al. (2019) point out that only $52 \%$ of respondents $(N=214)$ working at the level of the lower, middle, and strategic management agree that their organization solves unethical situations in an appropriate way. Only 32\% of respondents agreed that their organization had functional guidelines for dealing with such situations. Despite some limitations of this study, the findings can be considered important in terms of the development and innovation of the codes of ethics and standards for the provision of care.

The importance of innovation and the development of the codes of ethics in the light of the current situation (Covid-19 pandemic) is pointed out by Jia et al. (2020). In the conclusions of their qualitative study, which was carried out through a qualitative content analysis of 18 interviews with nurses, they point to the necessity of innovation in order to help nurses in solving ethically demanding life and work situations and ensuring safe and humanistic care. Hearing these needs and challenges can help nurses to prevent burnout and post-traumatic stress disorder, and to maintain mental health. As well as this, it can contribute to the development, personal and professional growth of nurses, as well as the improvement of the quality of provided care.

These review studies were created as part of a project that focuses on faith, culture, and traditions in today's culturally diverse society. The article aims to point out the importance and use of the codes of ethics in contemporary nursing in various countries and the need to innovate them in the Czech environment.

\section{Design}

A review study examining empirical research.

\section{Materials and methods}

Before starting this study, the research team asked a few basic questions. These were connected with; the topicality of the Code of Ethics for Nurses in the Czech Republic (Czech Association of Nurses, 2012) in light of events in the modern world; the importance of codes of ethics in nursing; and the perception of codes of ethics by nurses themselves. Based on these questions, the research team proceeded in accordance with the recommendations for the creation of a review study through the formulation of the research question PICO (Table 1).

\section{Search strategies}

With regard to the formulation of the research question, a search of the Cochrane Library was completed on 21 November 2020. Here, the database reviews and protocols were searched for. However, no publications that could provide comprehen-

Table 1. The criteria for the inclusion in the study according to PICO

\begin{tabular}{l|l}
\hline Population: & Nurse or student of nursing \\
\hline Intervention: & Codes of Ethics for Nurses in nursing practice \\
\hline Comparison: & Opinions and approaches of nurses to the code of ethics \\
\hline Outcome: & Ethical conflicts in nursing practice \\
\hline
\end{tabular}

sive answers to the basic questions identified by the research team were found. Therefore, another search was performed. The scientific databases WOS, PubMed, EBSCOhost, and ProQuest were used to find studies with the highest level of evidence. The searches in the databases were performed using predetermined keywords, which were Code of Ethics, Opinions of Nurses on the Code of Ethics, and Nursing Practice. As part of the search strategy, a combination of these keywords with "nurs" was chosen. We used the asterisk to expand the keyword with other possible connections, such as nurse and nursing, and therefore we were able to obtain studies that addressed the issue of nurses and nursing practice.

In the next phase of the search, the number of studies in the selected databases was reduced according to predetermined inclusion and exclusion criteria.

\section{Selection of studies}

The criteria for including a study were as follows. The studies had to be published from 1 January 2005 to the present, they had to be available in full text in English or Czech, and it had to be published research results. In order to select studies for the search, it was necessary that the individual studies met the requirements of a scientific publication with IMRaD (Introduction, Methods, Results, and Discussion). The criteria for excluding a study included the date of publication (i.e. before 1 January 2005), unavailability of the full version of the study, and in a language other than the specified language. Other exclusion criteria were that the publications were review studies or their content was not consistent with the PICO question.

After entering keywords, 980 studies were found in the databases (on 22 November 2020). After removing the studies that did not meet the inclusion criteria, 252 studies were available (Diagram 1). 35 were found in the Web of Science database, 38 in PubMed, 126 in EBSCO and 53 in ProQuest. After removing 99 duplicate studies, we received a research sample of 153 studies that were the subject of our study. The obtained studies were translated and subjected to content analysis. After a thorough inspection, 10 professional publications were included in the review article. They were in full text and corresponded to the focus of the researched problem.

\section{Data analysis and synthesis}

The procedure for source exclusion during the literature search is shown in Diagram 1.

The studies that were included in our research searched for data on: the authors of articles, year of publication, country of research, data on research methods, data on research sample groups, study duration, results and conclusions of the authors.

\section{Results and discussion}

In the literature search, 10 research studies were thoroughly analysed (Table 2). They describe the views of nurses around the world on the code of ethics. The Code of Ethics for Nurses is an essential part of this profession; thus, it is important to know how it is perceived by the nurses themselves and what impact it has on the performance of the nursing profession. Several studies addressing this issue have been conducted around the world.

First and foremost, it is important that nurses understand the code of ethics and can work with it in practice. A research survey published by Tadd et al. (2006) was carried out for three years in several countries (Great Britain, Finland, Italy, Greece, Poland, and the Netherlands). It was focused on the 


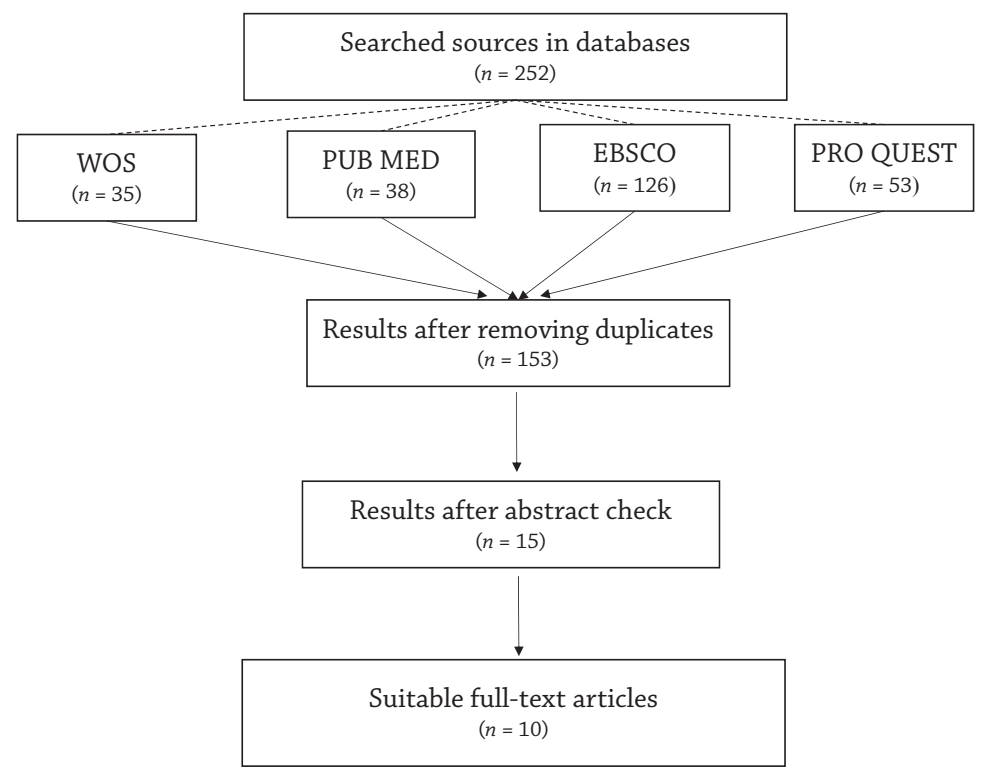

Diagram 1. Flow diagram - PRISMA

knowledge of the code of ethics and mapping the ethical values of nurses. 65 focus groups were surveyed in 6 countries and 22 interviews were conducted involving a total of 436 participants. The authors of the study state that, apart from Italian health professionals, who demonstrated sufficient knowledge of the codes of ethics, others did not have such an overview. Many nurses said that they knew about its existence but did not know exactly what its contents were. Nevertheless, most of them were able to describe the function of the codes of ethics in practice. According to them, this is a guide on how to behave in practice (Tadd et al., 2006). Many experts who deal with this issue have the same opinion as the nurses in this research.

This problem is illustrated by a research survey from Spain in 2014. It was quantitative research using a non-standardized questionnaire, which contained 28 questions related to knowledge of ethics, codes of ethics, and the associated existence of an ethics committee in a hospital. The majority of nurses (74.4\%) stated that ethics and codes of ethics in nursing practice are very important. More than $50 \%$ of nurses then stated that they had acquired knowledge in this area during their studies at universities. What is striking, however, is that although many nurses say they perceive the importance of codes of ethics and have knowledge in this area, $70 \%$ of them have no idea that there is an ethics committee within their hospital. The conclusions of this study also show that nurses are aware of the existence of the code of ethics but do not have sufficient knowledge to apply it in practice. Similar results have been obtained from other studies (Mohajjel-Agdam et al., 2013; Tadd et al., 2006). None of the nurses considered attending a course or training focused on this issue, although most of them had encountered an ethical problem during their practice. This was most often a patient's refusal of care due to religion (44\%) or a patient's wish to end their life (50\%) (Losa Iglesias and Becerro de Bengoa Vallejo, 2014).

Slightly different results are reported in a 2007 survey conducted in Finland, which also focused on nurses and their professional ethics and codes of ethics. Here, 342 nurses took part in the quantitative survey, but they also worked in the pedagogical sphere. Here the nurses rated their knowledge of the code of ethics as good, but it is interesting that compared to their colleagues in Spain (research survey Losa Iglesias and Becerro de Bengoa Vallejo, 2014), they attribute this knowledge not to educational institutions but rather to their own self-education. Most also stated that they had encountered the ethical question of whether or not to always tell patients the truth. Considering the fact that they also worked in pedagogical practice, they often discussed the issue of truth with their students, and it is the code of ethics that helps them better formulate individual ideas (Salminen et al., 2013).

In Gauteng Province, South Africa, research was conducted in 2015, which focused on nurses' views on the code of ethics, as well as the ethical conflicts that nurses encountered during their nursing practice. It was a questionnaire survey, which included 69 nurses from 5 hospitals. The results showed that nurses were aware of the importance of the codes of ethics in practice as well as certain responsibilities for the provided care (95\%). However, sometimes the nurses themselves perceived a contradiction with their own beliefs and the wording of the code of ethics (similar to the survey of Los Iglesias and Becerro de Bengoa Vallejo, 2014). Some nurses said they could not always respect a patient's religious beliefs. The majority of nurses (88\%) agreed with the statement that caring for homosexuals was against their ethical values. An interesting result is that nurses thought that too much emphasis was placed on patients' rights, sometimes even at the expense of nurses' rights (60\%) (White et al., 2015).

Another research study took place in South Korea in 2011. 303 nurses participated and the research was conducted in a quantitative form using a standardized questionnaire that was focused on moral sensitivity (K-MSQ). The subject of the research was the use of the code of ethics for nurses in practice. The results showed a similar finding as in previous research. Nurses strive to adhere to a certain code of ethics when providing care. However, sometimes they encounter an ethical problem that they do not know how to deal with. Most of the nurses stated that in such a case they will turn to one of their colleagues and try to solve the problem together. They literally 
Table 2. Selected studies focused on nurses' views of the codes of ethics

\begin{tabular}{|c|c|c|c|c|}
\hline Authors/year/country & Publication title & Study type/ Used tool & $\begin{array}{l}\text { Number of } \\
\text { respondents }\end{array}$ & Results \\
\hline $\begin{array}{l}\text { Heymans et al. (2007) } \\
\text { Netherlands }\end{array}$ & $\begin{array}{l}\text { Dutch nurses' views on codes of } \\
\text { ethics. Nursing Ethics. }\end{array}$ & $\begin{array}{l}\text { Qualitative study } \\
\text { Focus group ( } 5 \text { meetings) }\end{array}$ & 39 nurses & $\begin{array}{l}\text { Nurses have general knowledge of the } \\
\text { codes of ethics, and a lack of deeper } \\
\text { knowledge of the it. }\end{array}$ \\
\hline $\begin{array}{l}\text { Hlávková (2014) } \\
\text { Czech Republic - } \\
\text { Olomouc hospital }\end{array}$ & $\begin{array}{l}\text { Opinions of nurses on the codes } \\
\text { of ethics. }\end{array}$ & $\begin{array}{l}\text { Quantitative study } \\
\text { Questionnaire survey }\end{array}$ & 179 nurses & $\begin{array}{l}\text { Nurses know the code of ethics; they work } \\
\text { with it in practice. } \\
\text { They do not agree with some items of the } \\
\text { code. }\end{array}$ \\
\hline $\begin{array}{l}\text { Losa Iglesias and } \\
\text { Becerro de Bengoa } \\
\text { Vallejo (2014) } \\
\text { Spain }\end{array}$ & $\begin{array}{l}\text { Nurse attitudes in relation to } \\
\text { health care ethics and legal } \\
\text { regulations for nursing. }\end{array}$ & $\begin{array}{l}\text { Quantitative study } \\
\text { Questionnaire survey }\end{array}$ & 43 nurses & $\begin{array}{l}\text { The nurses know the code of ethics; they } \\
\text { try to follow it. } \\
\text { However, most do not know about the } \\
\text { presence of an ethics committee in the } \\
\text { hospital. }\end{array}$ \\
\hline $\begin{array}{l}\text { Mohajjel-Aghdam et al. } \\
\text { (2013) } \\
\text { Iran - Tabriz hospital }\end{array}$ & $\begin{array}{l}\text { Knowledge and Performance } \\
\text { about Nursing Ethic Codes from } \\
\text { Nurses' and Patients' Perspective } \\
\text { in Tabriz Teaching Hospitals, Iran. }\end{array}$ & $\begin{array}{l}\text { Quantitative study } \\
\text { Questionnaire survey }\end{array}$ & $\begin{array}{l}345 \text { nurses } \\
500 \text { patients }\end{array}$ & $\begin{array}{l}\text { Nurses evaluate their compliance with the } \\
\text { codes of ethics better than patients. } \\
\text { Knowledge of the codes of ethics is } \\
\text { reflected in job satisfaction. }\end{array}$ \\
\hline $\begin{array}{l}\text { Momennasab et al. } \\
\text { (2015) } \\
\text { Iran }\end{array}$ & $\begin{array}{l}\text { Nurses' adherence to ethical } \\
\text { codes: the viewpoints of patients, } \\
\text { nurses, and managers. }\end{array}$ & $\begin{array}{l}\text { Quantitative study } \\
\text { Questionnaire survey }\end{array}$ & $\begin{array}{l}100 \text { nurses } \\
100 \text { patients } \\
30 \text { managers }\end{array}$ & $\begin{array}{l}\text { Nurses strive to provide care in accordance } \\
\text { with the codes of ethics. } \\
\text { All groups rated compliance with the } \\
\text { codes of ethics as satisfactory. }\end{array}$ \\
\hline $\begin{array}{l}\text { Bijani et al. (2017) } \\
\text { Iran }\end{array}$ & $\begin{array}{l}\text { An evaluation of adherence to } \\
\text { ethical codes among nurses and } \\
\text { nursing students. }\end{array}$ & $\begin{array}{l}\text { Quantitative study } \\
\text { Questionnaire survey }\end{array}$ & $\begin{array}{l}222 \text { nurses } \\
178 \text { students }\end{array}$ & $\begin{array}{l}\text { Nurses and students have different views } \\
\text { on resolving ethical conflicts. } \\
\text { During their internship, students act } \\
\text { according to the codes of ethics more than } \\
\text { nurses. }\end{array}$ \\
\hline $\begin{array}{l}\text { Salminen et al. (2013) } \\
\text { Finland }\end{array}$ & $\begin{array}{l}\text { Nurse educators and professional } \\
\text { ethics - ethical principles and } \\
\text { their implementation from nurse } \\
\text { educators' perspectives. }\end{array}$ & $\begin{array}{l}\text { Quantitative study } \\
\text { Questionnaire survey }\end{array}$ & $\begin{array}{l}342 \text { nurses } \\
\text { (also } \\
\text { educators) }\end{array}$ & $\begin{array}{l}\text { They know the code of ethics and adhere } \\
\text { to it. } \\
\text { They face the ethical dilemma of telling } \\
\text { the truth to patients in all cases. }\end{array}$ \\
\hline $\begin{array}{l}\text { Tadd et al. (2006) } \\
\text { Great Britain, Finland, } \\
\text { Italy, Greece, Poland, } \\
\text { Netherlands }\end{array}$ & $\begin{array}{l}\text { The value of nurses' codes: } \\
\text { European nurses' views. }\end{array}$ & $\begin{array}{l}\text { Qualitative study } \\
\text { Focus group ( } 49 \text { groups) }\end{array}$ & 311 nurses & $\begin{array}{l}\text { The content of the codes is sometimes } \\
\text { incomprehensible. } \\
\text { It cannot always be fully used in practice. }\end{array}$ \\
\hline $\begin{array}{l}\text { White et al. (2015) } \\
\text { South Africa - province } \\
\text { Gauteng hospital }\end{array}$ & $\begin{array}{l}\text { Practice what you preach: Nurses } \\
\text { perspectives on the Code of Ethics } \\
\text { and Service Pledge in five South } \\
\text { African hospitals. }\end{array}$ & $\begin{array}{l}\text { Quantitative study } \\
\text { Questionnaire survey }\end{array}$ & 69 nurses & $\begin{array}{l}\text { Nurses know and follow the code of ethics. } \\
\text { Sometimes there is a conflict between a } \\
\text { nurse's own convictions and the wording } \\
\text { of the code. }\end{array}$ \\
\hline $\begin{array}{l}\text { Kim et al. (2012) } \\
\text { South Korean hospital }\end{array}$ & $\begin{array}{l}\text { Moral sensitivity relating to the } \\
\text { application of the code of ethics. } \\
\text { Nursing Ethics. }\end{array}$ & $\begin{array}{l}\text { Quantitative study } \\
\text { Standardized } \\
\text { questionnaire (K-MSQ) }\end{array}$ & 303 nurses & $\begin{array}{l}\text { The nurses strive to adhere to the code of } \\
\text { ethics. } \\
\text { They discuss ethical conflicts with their } \\
\text { colleagues. }\end{array}$ \\
\hline
\end{tabular}

agreed with the following statement: "In situations where it is difficult to find out what is right, I consult with my colleagues on how I can solve the situation." (Kim et al., 2012)

Looking at someone else's situation can help solve the problem effectively. Teacher nurses often discuss various ethical conflicts from practice with their students in order to obtain different opinions from people other than their colleagues - who may have been in practice for a long time and whose opinion may be influenced by previous experience. They also seek opinions from young students who have been in practice for a short time (Salminen et al., 2013).

Another study conducted in Iran in 2014 by Momennasab et al. (2015) also focused on the codes of ethics for nurses. Specifically, the observance of the codes of ethics in practice from the perspective of health professionals and patients. The survey involved 100 nurses and 100 patients, as well as $30 \mathrm{ex}^{-}$ ecutives from internal and surgical departments at a hospital in Shiraz, Iran. It was a questionnaire survey based on the code of ethics for nurses in clinical care. According to the results, all groups perceived compliance with the code of ethics in the hospital as satisfactory (nurses $86 \%$; patients $70 \%$; managers $53.3 \%$ ). Similar results were obtained from the nurses in the research of Mohajjel-Aghdam et al. (2013). According to Momennasab et al. (2015), the nurses stated that they respected the code of ethics more than their superiors. Managers were more critical of the areas of patient intimacy or cultural differences and religion, where they did not perceive nurses' behaviour as correct and appropriate according to the principles of the code of ethics.

A similar study was conducted in Iran in 2012, which also focused on code compliance and nurses' knowledge. The questionnaire survey was conducted at the University Hospital in Tabriz and it included 345 nurses and 500 patients. The majority of nurses $(86.4 \%)$ stated that they knew the code of ethics. However, the views of nurses and patients on the code of ethics differed significantly. In contrast to patients (41.8\%), 
nurses (91.9\%) believed that they always acted ethically on the basis of the codes. According to the nurses, their ethical behaviour included not accepting any gifts from patients and respecting patients as individuals. An interesting fact found in this survey was that there was a relationship between the nurses' knowledge of the codes of ethics and overall job satisfaction. The greater their knowledge the fewer ethical conflicts and issues they have that they would not have been able to cope with before. Therefore, they were more satisfied with their jobs (Mohajjel-Aghdam et al., 2013). Interestingly, nurses themselves rated their compliance with ethical codes as more satisfactory than their patients or managers (Mohajjel-Agdam et al., 2013; Momennasab et al, 2015).

An interesting comparative study was also conducted in 2017 in Iran. This too focused on the codes of ethics - but not only from the perspective of nurses in practice but also students of nursing. 400 people (178 students and 222 nurses) participated in the study, and data collection was performed using a questionnaire survey technique. According to the results, students paid more attention to various ethical issues in the provision of nursing care than the nurses themselves. However, students still lacked clinical practice to be able to address some of the complex ethical issues they faced in practice. Unlike these students, nurses could build on certain experiences - from both work and life. They also had a different set of values to young students. In this way, they were better acquainted, e.g., with the issue of patients' religion and the associated specifics of care. Students usually knew this only in theory (Bijani et al., 2017). However, sometimes differences in nurses' and patients' beliefs may arise and ethical conflict may occur (Kim et al., 2012; White et al., 2015).

The aim of another research study was to examine the views of Dutch nurses on the content, function, and implementation of the Code of Ethics for Nurses in practice in the Netherlands. The survey was conducted using the focus group technique and involved 39 nurses across the Netherlands. The individual groups included 6-7 nurses, who participated in 5 meetings. During the group meetings, it was found that it was difficult for nurses to discuss the content and meaning of the codes of ethics. Again, most nurses were generally aware of the code of ethics but did not know its exact content. According to the nurses, one of the reasons for their lack of awareness of the wording of the Code was that they were complex theoretical formulations that were often incomprehensible to them. The nurses then suggested that each new nurse could sign the code of ethics at registration to raise awareness of its content. One important result, however, is that while nurses do not always know the exact wording of the codes, they are aware of the presence of the codes and perceive them as a guide (Heymans et al., 2007). This conclusion is also consistent with a research survey in 6 European countries (Tadd et al., 2006).

The quantitative survey in the Czech Republic, which was carried out by Hlávková (2014), included 179 nurses from the hospital in Olomouc. The study also examined nurses' views on the code of ethics. The results showed that the nurses perceived the need for knowledge of the code of ethics, which all of them met with during their studies, whether in high school or university (100\%). However, they further stated that in practice they did not always have enough time to provide such care that would comply with the principles based on the code of ethics. An interesting result came from the area of co-responsibility of nurses for care outside healthcare facilities - which is contained in the code of ethics. Although it was a minority, some nurses stated that they did not agree with this point of the code of ethics (12\%).
Quite often, lack of time has emerged as a major argument for nurses across many hospitals. Nurses often stated that they could not always act precisely in accordance with the code of ethics because they did not have enough time and sometimes not enough aids (Hlávková, 2014; Kim et al., 2012; Momennasab et al., 2015), e.g., in the case of intimacy (patient during hygiene or other procedures) (Momennasab et al., 2015).

Most studies have reported that a large number of nurses know the codes of ethics in practice but sometimes lack knowledge of specific points of the code (Heymans et al., 2007; Losa Iglesias and Becerro de Bengoa Vallejo, 2014; Mohajjel-Aghdam et al., 2013; Tadd et al., 2006). However, they agree on the importance of the codes of ethics and that they are often very supportive in facing various ethical dilemmas (Heymans et al., 2007; Tadd et al., 2006; White et al., 2015).

Among the most common moral dilemmas that nurses deal with in practice in connection with the code of ethics are differences in life values based on the beliefs of the nurse and the patient (Losa Iglesias and Becerro de Bengoa Vallejo, 2014; Kim et al., 2012; White et al., 2015). In such cases, there may often be ethical conflicts that can lead to the patient's unwillingness to co-operate. Therefore, it is always better to prevent these things and, if possible, share such problems with colleagues and try to solve such a dilemma (Kim et al., 2012; Salminen et al., 2013). Codes of ethics help us to solve such problems and to behave properly.

\section{Conclusions}

The nursing profession is a demanding profession, both mentally and physically. It is associated with the occurrence of various ethically demanding professional and life situations. Nurses often find themselves in situations where a certain discrepancy can be observed between values, ethical beliefs, and the requirements of practice or demands placed upon them by the profession. Due to globalization, the political and economic situation, migration, and the occurrence of pandemics, the worldview orientation of care providers and their recipients is also changing. Of course, expertise (which includes education, theoretical and practical skills) is important for the performance of the nursing profession -, but equally important are the attitudes and opinions of the nurse. The codes of ethics act as a guide for dealing with certain situations requiring a sensitive ethical approach.

However, it is important to realize that the codes of ethics must not be just an unchanging guide that will remain the same from its inception. As medicine, nursing, nursing education, and their role in society move forward, it is necessary that the codes of ethics be updated as well. Last but not least, it is of course important to think of the patient, but it is no less important to think of the nurses. They too have rights - and these need to be defended. Recently, we have been reminded of the importance and necessity of this profession, how difficult this profession is, and how it is important for nurses to feel they also have a role to play.

It is, therefore, necessary to constantly innovate the codes of ethics according to the latest requirements of practice, acquaint nurses with their content, and, last but not least, remember to follow them - not only with regard to the duties of nurses, but also their rights.

\section{Conflict of interests}

The authors have no conflict of interests to declare. 


\section{Acknowledgements}

This paper is related to the research project entitled "Selected ethical aspects in the provision of healthcare and emergency assistance in a culturally diverse society", Reg. No. VEA202001, which is conducted with the financial support of the Grant
Agency of the University of South Bohemia in České Budějovice. Our literary research and its methodology were carried out in accordance with ethical rules and did not require any written consent of specific persons.

\section{Význam etických kodexů v ošetřovatelské péči}

\section{Souhrn}

Úvod: Etika sesterské profese je formulována Mezinárodním etickým kodexem sester, který je platný pro všechny sestry napříc celým světem. Význam tohoto kodexu je nesporný, zvláště v situacích, které vyžadují etické jednání. Avšak tak, jak se vyvíjí současný systém zdravotní péče, tomu musí odpovídat i obsah těchto kodexů. Podněty k těmto aktualizacím mohou dát právě sestry v praxi.

Cíl: Cílem je poukázat na význam a využití etických kodexů v současném ošetřovatelství v různých státech a na potřebu inovace etického kodexu v českém prostředí.

Metodika: Byla provedena literární rešerše na klíčová slova dle PICO s využitím booleovských operátorů. Odborné zdroje byly vyhledávány ve vědeckých elektronických databázích (EBSCO, PubMed, ProQuest, WOS).

Výsledky: Vyhledáno bylo celkem 252 zdrojů, kritické analýze bylo následně podrobeno 153 zdrojů, které splňovaly požadovaná kritéria. $Z$ toho počtu pak bylo k finální analýze využito 10 studií, které byly zaměřené na názory sester na etické kodexy a etické konflikty v praxi sester.

Závěr: Z prozkoumaných studií vyplývá, že sestry si uvědomují důležitost etického kodexu, většina o něm má obecné povědomí, ale mnoho sester neví, co je jeho přesným obsahem a jak by jim měl pomoci v praxi. Během poskytování ošetřovatelské péče se sestry setkávají s mnoha etickými dilematy, především pak v oblasti rozdílnosti některých hodnot. $V$ některých studiích bylo zjištěno, že sestry někdy vnímají, že práva pacientů jsou nad jejich právy. Je proto důležité, aby etické kodexy nezapomínaly podporovat práva samotných sester.

Klíčová slova: etický kodex; názory sester na etický kodex; ošetřovatelská praxe

\section{References}

1. Aitamaa E, Suhonen R, Puuka P, Leino-Kilpi H (2019). Ethical problems in nursing management - a cross-sectional survey about solving problems. BMC Health Serv Res 19: 417. DOI: 10.1186/s12913-019-4245-4.

2. Bijani M, Ghodsbin F, Fard SJ, Shirazi F, Sharif F, Tehranineshat B (2017). An evaluation of adherence to ethical codes among nurses and nursing students. J Med Ethics Hist Med 10: 6.

3. Czech Association of Nurses (2012). Etický kodex vypracovaný Mezinárodní radou sester. Česká asociace sester. [online] [cit. 2020-10-30]. Available from: https://www.cnna.cz/docs/ tiskoviny/eticky_kodex_icn_2012.pdf

4. Heymans R, van der Arend A, Gastmans C (2007). Dutch nurses' views on codes of ethics. Nurs Ethics. 14(2): 156-170. DOI: 10.1177/0969733007073696.

5. Hlávková E (2014). Názory zdravotních sester na etický kodex. Magisterská diplomová práce. Univerzita Palackého v Olomouci. Filozofická fakulta, katedra sociologie, andragogiky a kulturní antropologie. [online] [cit. 2020-10-30]. Available from: https:// theses.cz/id/i1z0mc/Diplomov_prce_Hlvkov.E.pdf

6. ICN - International Council of Nurses (2012). The ICN Code of Ethics for Nurses. International Council of Nurses, 3, place Jean-Marteau, 1201 Geneva, Switzerland. [online] [cit. 202010-30]. Available from: https://www.icn.ch/sites/default/files/ inline-files/2012_ICN_Codeofethicsfornurses_\%20eng.pdf

7. ICN - International Council of Nurses (2021). International Council of Nurses launches Consultation to revise Code of Ethics for Nurses, 21 October 2020. [online] [cit. 2020-10-30]. Available from: https://www.icn.ch/news/international-councilnurses-launches-consultation-revise-code-ethics-nurses

8. Jahromi M, Koshkaki A R, Poorgholami F, Talebizadeh M (2018). A Study of Nurses' Perception of Professional Values in the University Hospitals Affiliated with Jahrom University of Medical Sciences, 2015. Bangladesh J Med Sci 17(1): 47-51. DOI: 10.3329/bjms.v17i1.35279.

9. Jia Y, Chen O, Xiao Z, Xiao J, Bian J, Jia H (2020). Nurses' ethical challenges caring for people with COVID-19: A qualitative study. Nurs Ethics 28(1): 33-45. DOI: $10.1177 / 0969733020944453$.

10. Kim Y-S, Kang S-W, Ahn J-A (2012). Moral sensitivity relating to the application of the code of ethics. Nurs Ethics 20(4): 470-478. DOI: 10.1177/0969733012455563.

11. Losa Iglesias ME, Becerro de Bengoa Vallejo R (2014). Nurse attitudes in relation to health care ethics and legal regulations for nursing. Acta Bioethica 20(2): 255-264.

12. Meleis AI (2011). Theoretical Nursing: Development and Progress. 5th ed. Lippincott Williams \& Wilkins, $672 \mathrm{p}$.

13. Mohajjel-Aghdam A, Hassankhani H, Zamanzadeh V, Khameneh S, Moghaddam S (2013) Knowledge and Performance about Nursing Ethic Codes from Nurses' and Patients' Perspective in Tabriz Teaching Hospitals, J Caring Sci 2(3): 219-227. DOI: 10.5681/jcs.2013.027.

14. Momennasab M, Koshkaki AR, Torabizadeh C, Tabel SZ (2015). Nurses' adherence to ethical codes: The viewpoints of patients, nurses, and managers. Nurs Ethics 23(7): 794-803. DOI: 10.1177/0969733015583927.

15. Poorchangizi B, Farokhzadian J, Abbaszadeh A, Mirzaee M, Borhani F (2017). The importance of professional values from clinical nurses' perspective in hospitals of a medical university in Iran. BMC Med Ethics 18(1): 20. DOI: 10.1186/s12910-0170178-9.

16. Salminen L, Metsämäki R, Numminen OH, Leino-Kilpi H (2013) Nurse educators and professional ethics--ethical principles and their implementation from nurse educators' perspectives. Nurse Educ Today. 33(2): 133-137. DOI: 10.1016/j.nedt.2011.11.013.

17. Tadd W, Clarke A, Lloyd L, Leino-Kilpi H, Strandell C, Lemonidou C, et al. (2006). The value of nurses' codes: European nurses' views. Nurs Ethics 13(4): 376-393. DOI: $10.1191 / 0969733006$ ne891oa. 
18. White J, Phakoe M, Rispel LC (2015). 'Practice what you preach': Nurses' perspectives on the Code of Ethics and Service Pledge in five South African hospitals. Glob Health Actio. 8: 26341. DOI: 10.3402/gha.v8.26341.

19. WHO (2020). WHO and partners call for urgent investment in nurses. [online] [cit. 2020-10-30]. Available from: https://www. who.int/news/item/07-04-2020-who-and-partners-call-forurgent-investment-in-nurses

20. Zarshenas L, Sharif F, Molazem Z, Khayyer M, Zare N, Ebadi A (2014). Professional socialization in nursing: A qualitative content analysis. Iran J Nurs Midwifery Res 19(4): 432-438. 